\title{
Carbon Sequestration under Warm Season Turfgrasses in Home Lawns
}

\author{
Said A. Hamido' ${ }^{*}$, E. A. Guertal2 ${ }^{2}$ C. Wesley Wood $^{3}$ \\ ${ }^{1}$ Southwest Florida Research and Education Center, University of Florida, Immokalee, FL, USA \\ ${ }^{2}$ Crop, Soil and Environmental Sciences Department, Auburn University, Auburn, AL, USA \\ ${ }^{3}$ West Florida Research and Education Center, University of Florida, Milton, FL, USA \\ Email:`shamido@ufl.edu,guertea@auburn.edu,woodwes@ufl.edu
}

How to cite this paper: Hamido, S.A., Guertal, E.A. and Wesley Wood, C. (2016) Carbon Sequestration under Warm Season Turfgrasses in Home Lawns. Journal of Geoscience and Environment Protection, 4, 5363.

http://dx.doi.org/10.4236/gep.2016.49005

Received: August 18, 2016

Accepted: September 16, 2016

Published: September 19, 2016

Copyright (c) 2016 by authors and Scientific Research Publishing Inc. This work is licensed under the Creative Commons Attribution International License (CC BY 4.0).

http://creativecommons.org/licenses/by/4.0/

(c) (i) Open Access

\begin{abstract}
Turfgrass cover in the U.S. is expanding because of increasing urbanization and the addition of approximately 675,000 ha of residential property every year. Despite its large-scale presence in the urban ecosystem, the role of turfgrasses in carbon (C) cycling in home lawns in southeastern U.S. soils has not been documented, and studies with warm-season turf grasses are lacking. The objective of this study was to estimate carbon (C) sequestration in soil as affected by turfgrass species, including: bermudagrass (Cynodon dactylon (L.) Pers. $\times$ C. transvaalensis Burtt Davy), centipede grass (Erecholmoa ophroides (Munroe) Hack.), and zoysiagrass (Zoysia spp.). The study was initiated in the winter of 2012 and conducted for two years on a loamy sand (fine-loamy, kaolinitic, thermic Typic Kanhapludult) soil. Eighteen lawns were sampled twice per year: six lawns of each grass species, with the harvested grasses separated into stems, above ground biomass (verdure) + thatch, and belowground roots. Soil samples $(0-5,5-10$, and $10-20 \mathrm{~cm})$ were also collected. Total $\mathrm{C}$ concentration was determined on finely ground-dried samples by combustion. Turfgrass species, season and years of sampling were all significantly $(\mathrm{P} \leq 0.05)$ affected by $\mathrm{C}$ sequestration. Zoysiagrass had the highest mean levels of sequestered $\mathrm{C}$, with a value of $5.54 \pm 0.21$, compared to $2.09 \pm 0.11$ and $4.23 \pm 0.14 \mathrm{Mg} \cdot \mathrm{ha}^{-1} \cdot \mathrm{yr}^{-1}$ under bermudagrass and centipedegrass at the end of the study, respectively. This work indicates that turfgrass home lawns may be an important contribution to the global carbon sequestration level.
\end{abstract}

\section{Keywords}

Carbon Sequestration, Soil Organic Carbon, Bermudagrass, Centipedegrass, Zoysiagrass 


\section{Introduction}

Understanding the role of soils as a sink or a source for Carbon on a global scale is critical for evaluating changes in atmospheric carbon dioxide $\left(\mathrm{CO}_{2}\right)$ concentration [1]. Land use change can alter soil $\mathrm{C}$ pools and can have a significant effect on the $\mathrm{C}$ balance between soils and the atmosphere. For example, conversion of forest to row crops results in depletion of soil organic carbon (SOC) by an average of 35\% [2]. Trumbore et al. [3] found that when tropical dry forest in eastern Amazonia was converted to pasture, it lost an estimated value of $130 \mathrm{~kg} \mathrm{SOC} \mathrm{ha}^{-1} \cdot \mathrm{yr}^{-1}$ from the top $10 \mathrm{~cm}$ of soil profile. In another part of eastern Amazonia, when moist tropical forest was converted to pasture, it lost about $300 \mathrm{~kg} \mathrm{SOC} \mathrm{ha-1} \cdot \mathrm{yr}^{-1}$ within the top $40 \mathrm{~cm}$ of soil [4]. In addition, rates of SOC sequestration under a subtropical wet forest plantation were higher than under a cool temperate-zone pine plantation, with an average accumulation of $338 \mathrm{~kg} \mathrm{C}$ $\mathrm{ha}^{-1} \cdot \mathrm{yr}^{-1}$ [5]. However, perennial grasses are more effective than woody plants at sequestering C in soil [5]. Baskin and Binkley [6] reported that significant changes in C sequestration were found when sugarcane fields were converted to fast growing eucalyptus plantations. After 10 - 15 years, SOC increased under eucalyptus in Hawaii by an average of $19.4 \mathrm{Mg} \cdot \mathrm{ha}^{-1}$ in the top $55 \mathrm{~cm}$ of soil. Thus, the amount of organic $\mathrm{C}$ stored in soils varies with ecosystems and land use change [7].

Most of the work on $\mathrm{C}$ sequestration has been conducted in row crops or forest ecosystems. There has been no work done on cool-season turf grasses, which indicated that golf course soils and home lawn soils sequestered carbon, but such $\mathrm{C}$ storage was offset by $\mathrm{C}$ emissions from fuel combustion, $\mathrm{N}$ fertilizer and irrigation [8] and [9]. Carbon sequestration in turfgrass may also be different from row-crop or forests because intensive management practices such as fertilization, irrigation, mowing and use of fuel-using power equipment affect $\mathrm{C}$ flux [10]. Little research has focused on contributions from warm season turfgrasses such as bermudagrass, centipedegrass, and zoysiagrass. The turfgrass sector is a large industry with a sizable impact on the landscape of urban environments. The economic impact of turfgrass has been estimated to be $\$ 62.2$ billion in the U.S., in 2005 [11]. Nationally, the turfgrass industry generates 822,849 jobs, $\$ 37.7$ billion in labor income, and $\$ 2.4$ billion in indirect business taxes [11].

Milesi et al. [12] estimated the total U.S. turfgrass area to be $163,800 \pm 35,850 \mathrm{~km}^{2}$. Turfgrass cover in the U.S. is rapidly expanding because of increasing urbanization and the addition of approximately 675,000 ha of residential property each year [13]. These areas of extensive grass cover could have a significant effect on soil C sequestration. For example, soils developed under temperate grassland sequestered a C mass of 192

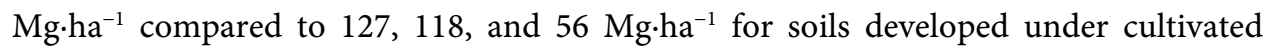
agriculture, temperate forest, and desert scrub, respectively [14].

A later study evaluated C sequestration under different turfgrass species [15]. Cool season grasses such as fine fescue (Festuca rubra L.) (both irrigated and non-irrigated), Kentucky blue grass (Poa pratensis L.) (irrigated), and creeping bent grass (Agrostis stolonifera L.) (irrigated) were evaluated for changes in SOC, soil C sequestration and soil organic $\mathrm{C}$ decomposition. Four years after establishment, approximately $17 \%$ to 
$24 \%$ of SOC ( $0-10 \mathrm{~cm}$ depth) was contributed by the established turfgrass. Increases in SOC differed with turfgrass species and irrigation, with irrigated fine fescue having the highest SOC, estimated to be $3.4 \mathrm{Mg} \mathrm{C} \mathrm{ha}^{-1} \cdot \mathrm{yr}^{-1}$. All turfgrass species sequestered $\mathrm{C}$ during the first four years after turf establishment, with the highest rates for irrigated fine fescue and creeping bent grass [15].

There is a limited study which examines $C$ dynamics in the long-term, non-tilled setting with warm-season turfgrass management. Warm season turfgrasses (when grown in the southeast U.S.) are additionally novel in that they are dormant or quasi-dormant after a severe frost, regaining color and growth in the spring. Also, many of warm-season turfgrass species grow via above-and below-ground stem structures (stolons and rhizomes, respectively), and these structures affect carbohydrate storage within the plant, which may further affect $\mathrm{C}$ storage. Thus, there is a need to evaluate $\mathrm{C}$ dynamics in warm-season turfgrass lawns in the southeast U.S. The objective of this study was to study $\mathrm{C}$ sequestration in warm-season turfgrasses managed in the home lawn environment, examining this sequestration as affected by grass species.

\section{Materials and Methods}

\subsection{Study Sites}

This two-year study (2012 and 2013) was conducted on randomly selected home lawns located in Auburn, AL $\left(32.598^{\circ} \mathrm{N}, 85.481^{\circ} \mathrm{W}\right)$. Every lawn was within $1.6 \mathrm{~km}$ radius from other locations, and all lawns were of a similar age (the neighborhood in which the lawns were sampled largely had houses that dated to the 1950s and 1960s). All lawns were grown under similar soil type and environmental conditions including rainfalls and temperatures. In addition, they represent the most common turfgrasses in the southeastern U.S. From a survey of the homeowners, none of the lawns were new, and the averaged estimated age of the sampled lawns was more than 20 years. In all cases the soil type was a Marvyn loamy sand soil (fine-loamy, kaolinitic, thermic Typic Kanhapludult). Three turfgrass species were included in the study: bermudagrass, centipede grass and zoysiagrass. Cultivars were most likely: "common" centipede grass (all 6 sites), "Tifway" hybrid bermudagrass (all 6 sites) and "Emerald" (5 sites) or "Meyer" (1 site) zoysiagrass, all typical and available cultivars for 20 -year old home lawns. Six lawns of each turfgrass species were sampled, for a total 18 lawns.

For this study, we had no control over mowing, clipping removal or fertilization procedures for these lawns. However, a brief interview was conducted with each homeowner, and the following general management strategy was found for each lawn. Of the 18 lawns, eight were managed using the services of a home-lawn care company ( 2 centipedegrass, 3 each zoysiagrass and bermudagrass), with a total of 4 different companies for those lawns. All the other lawns were managed by the homeowners. Height of cut was determined by measuring verdure at harvest and was as follows: bermudagrass and zoysiagrass both at 5.0 to $6.3 \mathrm{~cm}$, and centipedegrass and 6.3 to $7.5 \mathrm{~cm}$. All mowing was done weekly using a rotary mower with clippings removed (in Auburn, AL clippings may still be piled at the curb for pickup, and most homeowners still engage in this 
practice). In all 2 zoysiagrass lawns and 1 bermudagrass lawn were irrigated using an installed in-ground system, with irrigation applied to supply water if drought occurred. All other lawns were rain fed. Selected sampled lawns were in an older and long established neighborhood, and in-ground irrigation is not common in these older landscaped lawns. For all lawns, weed control consisted of one fall application of a preemergent herbicide for general control of winter annual weeds (primarily Poa annua), plus one application of a summer post-emergent broadleaf herbicide as needed. Last, fertilization was almost exclusively nitrogen applied as urea (46-0-0) or a mixed blend (10-10-10 or 13-13-13, N- $\mathrm{P}_{2} \mathrm{O}_{5}-\mathrm{K}_{2} \mathrm{O}$ ) with a total yearly $\mathrm{N}$ rate of $9.8 \mathrm{~g} \mathrm{~N} \mathrm{~m}^{-2} \cdot \mathrm{yr}^{-1}$ (applied as split applications in May and July, typically) for bermudagrass and zoysiagrass. Five of the centipedegrass lawns were never fertilized in the two year period, and the sixth received one application of $4.9 \mathrm{~g} \mathrm{~N} \mathrm{~m}^{-2} \cdot \mathrm{y}^{-1}$.

\subsection{Turf and Soil Sampling Procedures}

Each lawn was sampled twice a year, in the summer (July) and in the winter (January), when the lawns were not growing or dormant. At each sampling six samples $(5.0 \mathrm{~cm}$ diameter to a final depth of $20 \mathrm{~cm}$ ) were collected using a hand-sampler from each lawn, with the samples taken randomly from each lawn. Fresh samples were taken to the laboratory, where they were immediately separated into tissue and soil components, as follows. Three of the samples were used for tissue sampling, with that sample separated into: 1) above ground growth (verdure) plus thatch (the intermingled live and dead plant tissue just below the shoots and above the soil), 2) stems (stolons and/or rhizomes), and, 3) roots. The remaining three samples were used for soil analysis, with those samples separated into the depth increments $0-5,5-10$, and $10-20 \mathrm{~cm}$.

Soil samples were air dried and then ground to pass a 100-mesh sieve. Those samples were used for organic $\mathrm{C}$ analysis. Tissue samples were oven dried at $50^{\circ} \mathrm{C}$ for $48 \mathrm{hr}$ and then ground (by hand) to pass a 100 mesh sieve for organic $\mathrm{C}$ analysis. Initial pre-experiment assays with harvested tissue indicated that the previously mentioned drying temperatures and times result in a constant weight of dry tissue. Total $\mathrm{C}$ concentration was determined on finely ground oven-dried stem (rhizomes, stolons, and roots), above-ground tissue of turfgrass plus thatch and soil samples via dry combustion using a LECO TruSpec CN (LECO Corp., St. Joseph, MI).

\subsection{Bulk Density}

Bulk density was determined from core samples collected with a slide hammer (AMS, Inc., Sampling Equipment, American Falls, ID), with adjustment for rock content using the USDA procedure [16].

\subsection{Carbon Sequestration Calculation}

Sequestered C was calculated as described by [17] as follows:

$$
\mathrm{C} \mathrm{Mg} \cdot \mathrm{ha}^{-1}=(\% \mathrm{C} / 100) * \mathrm{BD} * \mathrm{D} *\left(10000 \mathrm{~m}^{2} \cdot \mathrm{ha}^{-1}\right)
$$


where:

$\% \mathrm{C}=$ Mean percent of carbon content in soil

$\mathrm{BD}=$ Mean bulk density (in $\mathrm{Mg} \cdot \mathrm{m}^{-3}$ )

$\mathrm{D}=$ Soil depth $(\mathrm{m})$

Stored C in biomass was calculated using $\mathrm{C} \%$ and dry mass as follows:

$$
\mathrm{C} \mathrm{Mg} \cdot \mathrm{ha}^{-1}=(\% \mathrm{C} / 100) \times \operatorname{dry} \text { mass }\left(\mathrm{Mg} \cdot \mathrm{ha}^{-1}\right) \text {. }
$$

\subsection{Data Analysis}

Differences in C sequestration due to grass species were determined via analysis of variance using the mixed model procedure (SAS Institute Inc., Cary, NC). Season of measurement and year were considered as repeated measures; depth of each lawn used as the main variable and fixed effect. Denominator degrees of freedom were calculated using the Kenward-Roger option. Means were compared using Pairwise Multiple Comparison Procedures (Tukey's Test) at $\mathrm{P}<0.05$.

\section{Results and Discussion}

Neither year nor season (winter or summer) had a significant effect on soil $\mathrm{C}$ in the year $\times$ grass $\times$ depth $(P=0.3018)$, year $\times$ depth $(P=0.1212)$, season $\times$ depth $(P=$ $0.3114)$, or season $\times$ grass $\times$ depth $(P=0.9268)$ interaction. This indicates that, within our relatively narrow two-year sampling period, soil C was relatively stable across year and month of sampling. The interaction of grass $\times$ depth was always significant $(\mathrm{P}<$ 0.0001 ), indicating that grass species sequestered $C$ differently with depth. Regardless of sampling date and year, there were significant differences in soil $\mathrm{C}$ accumulation as affected by turfgrass species $(\mathrm{P}<0.05)$. Among all turfgrass species, $\mathrm{C}$ sequestered in underlying soil was highest in zoysiagrass lawns and lowest in bermudagrass lawns. The amount of soil C stored in zoysiagrass lawns was estimated at $2.33 \mathrm{Mg} \cdot \mathrm{ha}^{-1} \cdot \mathrm{yr}^{-1}, 2.5$ times greater than measured in bermudagrass lawns $\left(0.92 \mathrm{Mg} \cdot \mathrm{ha}^{-1} \cdot \mathrm{yr}^{-1}\right)$ in the top soil surface $(0-5 \mathrm{~cm})$ (Figure 1$)$. When soil $\mathrm{C}$ was summed for the three sampling depths zoysiagrass had greatest soil $\mathrm{C}$, followed by centipedegrass, and then bermudagrass. Zoysiagrass is generally considered to be a turfgrass with higher shoot densitythan lawn-type hybrid bermudagrass, especially for the Emerald cultivar (a fine-textured zoysiagrass) which predominated in this study. Thus, the greater shoot density of zoysiagrass may have created more biomass and a greater potential pool of soil $\mathrm{C}$ in that turfgrass.

In the upper $20 \mathrm{~cm}$ of soil, significant variation in accumulated $\mathrm{C}$ among turfgrass species was observed $(\mathrm{P}<0.0001)$. For example, the amount of soil $\mathrm{C}$ stored $(0-20 \mathrm{~cm})$ in zoysiagrass lawns was $5.14 \pm 0.21 \mathrm{Mg} \cdot \mathrm{ha}^{-1} \cdot \mathrm{yr}^{-1}$, compared to $1.8 \pm 0.11$ and $3.7 \pm 0.14$ $\mathrm{Mg} \cdot \mathrm{ha}^{-1} \cdot \mathrm{yr}^{-1}$ in bermudagrass and centipedegrass lawns, respectively (Figure 1). Carbon stored in soil under zoysiagrass was almost three times greater than that found in soil under bermudagrass. The amount of carbon stored in bermudagrass soils was comparable to the $1.4 \mathrm{Mg} \mathrm{C} \mathrm{ha}{ }^{-1} \cdot \mathrm{yr}^{-1}$ stored in the top $20 \mathrm{~cm}$ of soil under ornamental lawns [18]. The reason behind higher accumulation of organic $\mathrm{C}$ under zoysiagrass 


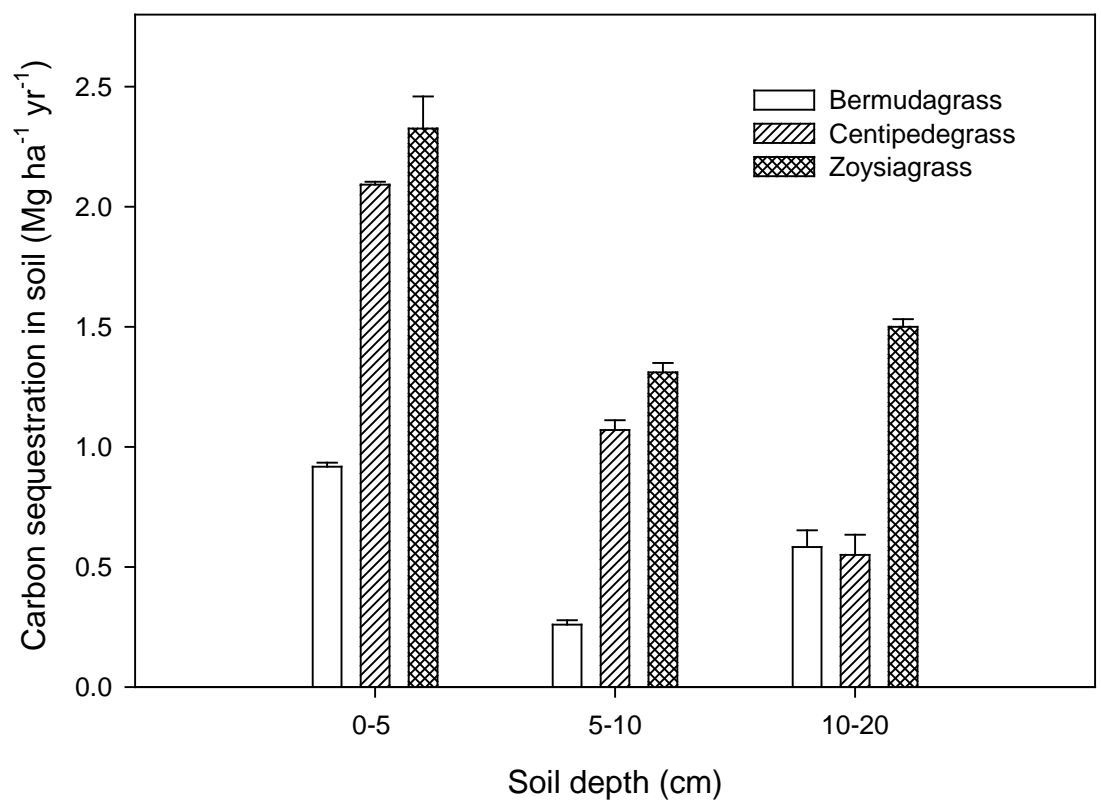

Figure 1. Carbon sequestration $\left(\mathrm{Mg} \cdot \mathrm{ha}^{-1} \cdot \mathrm{yr}^{-1}\right)$ in soil as affected by turfgrass species and soil depth. Bars show the standard error of the mean.

may again be explained by a typically greater shoot density as compared to bermudagrass and centipedegrass, which might have resulted in higher $\mathrm{C}$ sequestration in zoysia grass compared to bermudagrass and centipedegrass.

Plant $\mathrm{C}$ is added to soil by deposition and decomposition of aboveground plant parts (litter decomposition) and belowground root exudates [19]. In our study, carbon stored in roots was less than that measured in the surrounding soil, and was greatest in the top layer $(0-5 \mathrm{~cm})$ (Figure 2(a)). Major sources of SOC accumulation are from belowground plant root activities [20] and aboveground biomass decomposition. Root densities of turfgrasses typically decline with depth, while decomposition of clippings and stems at or near the soil surface enriches the upper soil with C. These combined effects demonstrate why highest $\mathrm{C}$ accumulation in roots was measured in the $0-5 \mathrm{~cm}$ layer, with declines with depth (Figure 2(a)). In all cases $C$ sequestration in roots decreased with depth. Greatest $\mathrm{C}$ storage was in zoysiagrass roots, followed by centipedegrass and then bermudagrass.

The intensity of root exudates varies with different compositions of plant tissues [21]. For example, more than $45 \%$ of the $\mathrm{C}$ assimilated by trees is ultimately transported belowground via root growth and root exudates, making soil a significant sink of C [22]. Reyes-Reyes et al. [23] and Yelenik et al. [24] observed an increase in belowground C stock when grass dominated ecosystems were invaded by a tree population in the central highlands of Mexico. Similarly, silvopasture systems were observed to have a greater accumulation of $\mathrm{C}$ in soil when compared with adjacent pastures (tree free) in Florida [25].

Carbon sequestration in roots significantly $(\mathrm{P} \leq 0.05)$ varied by depth among grass species with season $(P=0.0010)$ and year $(P<0.0001)$. The two-way interactions grass $\times$ 

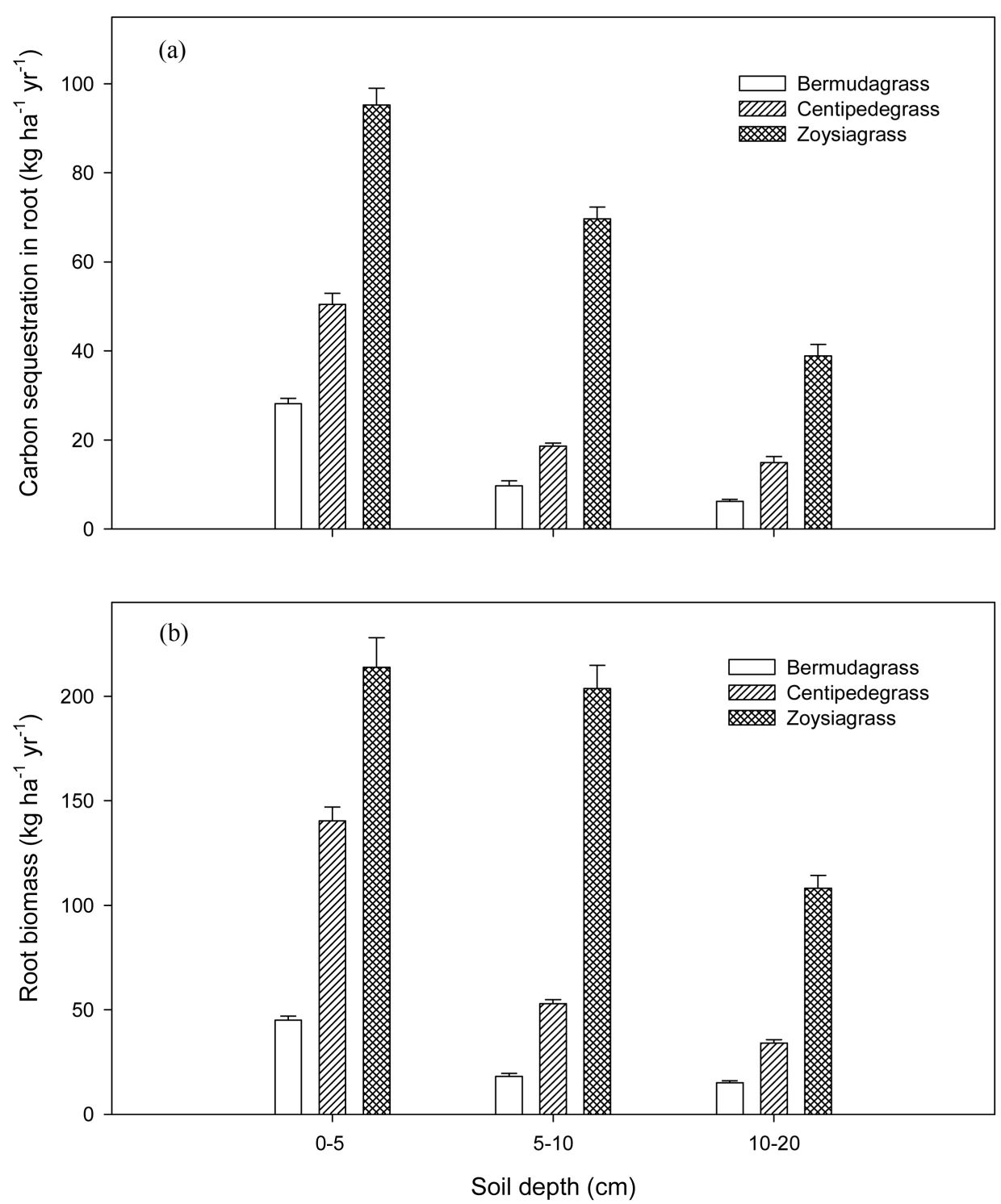

Figure 2. Effect of grass species and soil depth on carbon sequestration $\left(\mathrm{kg} \cdot \mathrm{ha}^{-1} \cdot \mathrm{yr}^{-1}\right)$ in grass root (a), and, weight of root biomass (b). Bars show the standard error of the mean.

depth and grass $\times$ year significantly $(\mathrm{P}<0.0001)$ affected $\mathrm{C}$ accumulation in the roots. The amount of $\mathrm{C}$ stored in grass roots in the 5 to $10 \mathrm{~cm}$ layer was higher in the zoysiagrass lawns $\left(69.7 \pm 2.7 \mathrm{~kg} \cdot \mathrm{ha}^{-1} \cdot \mathrm{yr}^{-1}\right)$ compared to bermudagrass and centipedegrass lawns $\left(9.7 \pm 1.2\right.$ and $18.6 \pm 0.7 \mathrm{~kg} \cdot \mathrm{ha}^{-1} \cdot \mathrm{yr}^{-1}$ ) respectively) (Figure 2(a)). A decline in C from roots was observed as sampling depth increased.

Differences in accumulated $\mathrm{C}$ content among grasses can be explained by the differences in grass root biomass (Figure 2(b)) and, possibly, anthropogenic activities such as clipping frequency and fertilization, which impact the above ground biomass, affecting $\mathrm{C}$ transported belowground and partitioned in root growth. When actual root biomass was measured (Figure 2(b)), both centipedegrass and zoysiagrass had greater rooting at all depths. The difference in rooting density at lower depths is probably the 
reason for the difference in $\mathrm{C}$ accumulation. The difference in SOC between the top and bottom soil layer was the highest (75\%) in centipedegrass. This difference may be due to the fact that centipedegrass is the sole turfgrass in this study that has only stoloniferous growth (above-ground stems), and not both stolons and rhizomes (above- and below-ground stems, respectively). Thus, extensive rhizomes in zoysiagrass and bermudagrass may have contributed to SOC deeper in the profile due to decomposition of rhizomes.

Above ground biomass had significant variation in accumulated $\mathrm{C}$ among selected turfgrasses with year $(P<0.0001)$. The two-way interaction between grass $\times$ year was very significantly $(\mathrm{P}=0.0066)$ affected by $\mathrm{C}$ accumulation in the aboveground biomass. For example, $\mathrm{C}$ sequestered in the aboveground biomass of zoysiagrass was the highest, $0.11 \pm 0.008 \mathrm{Mg} \cdot \mathrm{ha}^{-1} \cdot \mathrm{yr}^{-1}$ compared to $0.088 \pm 0.008$ and $0.056 \pm 0.018 \mathrm{Mg} \cdot \mathrm{ha}^{-1} \cdot \mathrm{yr}^{-1}$ in bermudagrass and centipedegrass, respectively (Figure $3(\mathrm{a})$ ). Differences in sequestered $\mathrm{C}$ in verdue were a function of aboveground biomass (Figure 3(b)).

Significant variation in accumulated $\mathrm{C}$ among turfgrass species was found in thatch and stem tissue $(\mathrm{P}<0.0001)$. The two-way interaction grass $\times$ year and grass $\times$ season and the three-way interaction grass $\times$ year $\times$ season significantly $(\mathrm{P}<0.0001)$ affected $\mathrm{C}$ accumulation in stems. For example, $\mathrm{C}$ sequestered in the thatch layer + stolons/rhizomes of zoysiagrass increased from $0.70 \pm 0.03$ (January 2012) to $0.74 \pm 0.03 \mathrm{Mg} \cdot \mathrm{ha}^{-1}$ (July 2103) a 6\% increase. The amount of $\mathrm{C}$ accumulated in stolon/rhizome of bermudagrass increased from $0.33 \pm 0.02$ (January 2012) to $0.38 \pm 0.03 \mathrm{Mg} \cdot \mathrm{ha}^{-1} \cdot \mathrm{yr}^{-1}$ (July 2103), a $13 \%$ increase. Carbon stored in centipedegrass (thatch layer + stolons only) was $0.10 \pm 0.01 \mathrm{Mg} \cdot \mathrm{ha}^{-1} \cdot \mathrm{yr}^{-1}$, which is two times greater than in zoysiagrass lawns, which was $0.05 \pm 0.001 \mathrm{Mg} \cdot \mathrm{ha}^{-1} \cdot \mathrm{yr}^{-1}$ (Figure $3(\mathrm{c})$ ). Differences in accumulation of $\mathrm{C}$ may be explained by the differences in stolon/rhizome biomass under all grasses (Figure 3(d)). Statistical analyses indicated that turfgrass species, season and year sampling significantly $(\mathrm{P} \leq 0.05)$ affected total (including soil, roots, thatch + rhizome/stolon, and aboveground mass) $\mathrm{C}$ sequestration in the soil profile. The two-way interaction grass $\times$ year affected significantly $\mathrm{C}$ accumulation in the top $20 \mathrm{~cm}$ of soil depth $(\mathrm{P}=0.04)$. Zoysia grass had highest levels of sequestered $\mathrm{C}$ with a total (soil, roots, thatch + rhizome/stolon, and aboveground mass) value of $5.54 \pm 0.21$, compared to $2.09 \pm 0.11$ and $4.23 \pm 0.14 \mathrm{Mg} \cdot \mathrm{ha}^{-1} \cdot \mathrm{yr}^{-1}$ under bermudagrass and centipedegrass systems, respectively. Accumulated C content differences among grasses can be explained by the differences in grass biomass and human activities such mowing frequency, fertilization or clipping removal, in addition to environmental factors including soil and air temperature, soil moisture, and structure.

\section{Conclusions}

Grassland is a major component of the terrestrial ecosystem, comprising $27 \%$ of the total US area [26]. These areas are vital to global C sequestration, and may act as sources or sinks for $\mathrm{C}$ at a significant level [27]. Due to that large area of land covered by grass, even a very small change in management practices to reduce $\mathrm{C}$ emissions may be an 

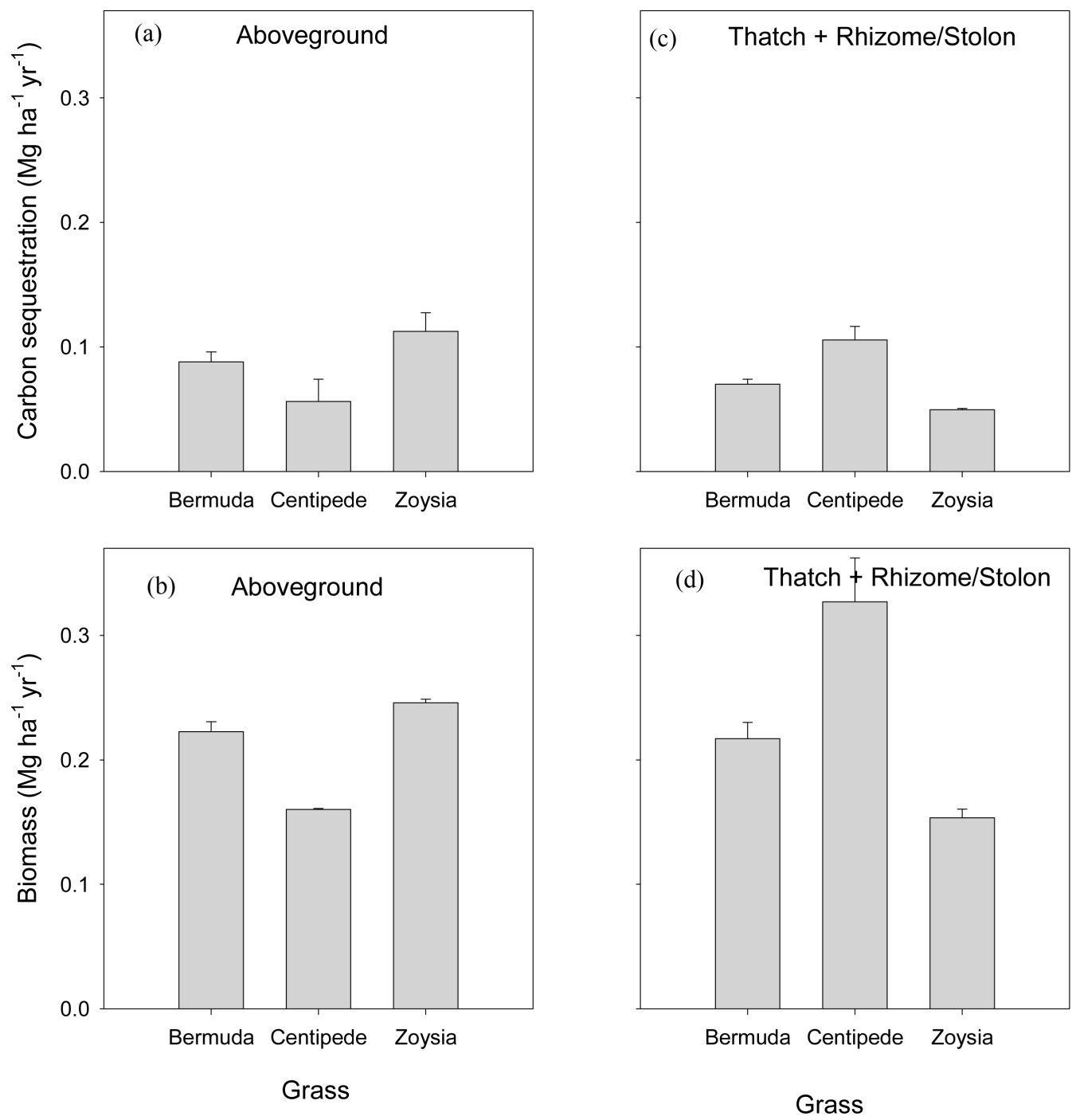

Figure 3. Effect of grass species on carbon sequestration $\left(\mathrm{Mg} \cdot \mathrm{ha}^{-1} \cdot \mathrm{yr}^{-1}\right)$ in aboveground (a) and thatch layer + rhizome/stolons (c), and weight of aboveground biomass (b) and weight of thatch layer + rhizome/stolon (d). Bars show the standard error of the mean.

important contribution to the global $\mathrm{C}$ sequestration level. For example, $\mathrm{CO}_{2}$ emission was reduced in bermudagrass by reductions in nitrogen fertilization [28] and [29]. Carbon storage in lawns could also be increased by reducing mowing, and returning clippings. This study found that zoysiagrass had greater above- and below-ground biomass that resulted in greater $\mathrm{C}$ inputs to the soil than other warm-season turfgrasses, likely due to the individual or combined effects of species and plant density. However, more research is needed on inputs such as litter quality and quantity, mowing, irrigation and clipping management to better quantify $\mathrm{C}$ flux in home lawns.

\section{References}

[1] Johnson, D.W. and Curtis, P.S. (2001) Effects of forest Management on Soil C and N Storage: A Meta-Analysis. Forest Ecology and Management, 140, 227-238. 
http://dx.doi.org/10.1016/S0378-1127(00)00282-6

[2] Post, W.M. and Mann, L.K. (1990) Changes in Soil Organic Carbon and Nitrogen as a Result of Cultivation. In: Bouwman, A.F., Ed., Soils and the Greenhouse Effect, John Wiley and Sons, New York, 401-406.

[3] Trumbore, S.E., Davidson, E.A., Camargo, P.B., Nepstad, D.C. and Martinelli, L.A. (1995) Belowground Cycling of Carbon in Forests and Pastures of Eastern Amazonia. Global Biogeochemical Cycles, 9, 515-528. http://dx.doi.org/10.1029/95GB02148

[4] Desjardins, T., Andreux, F., Volkoff, B. and Cerri, C.C. (1994) Organic Carbon and ${ }^{13} \mathrm{C}$ Contents in Soils and soil Size-Fractions and Their Changes Due to Deforestation and Pasture Installation in Eastern Amazonia. Geoderma, 61, 103-118.

http://dx.doi.org/10.1016/0016-7061(94)90013-2

[5] Post, W.M. and Kwon, K.C. (2000) Soil Carbon Sequestration and Land-Use Change: Processes and Potential. Global Change Biology, 6, 317-327.

http://dx.doi.org/10.1046/j.1365-2486.2000.00308.x

[6] Baskin, M. and Binkley, D. (1998) Changes in Soil Carbon Following Afforestation in Hawaii. Ecology, 79, 828-833. http://dx.doi.org/10.1890/0012-9658(1998)079[0828:CISCFA]2.0.CO;2

[7] Guo, Y., Amundson, R., Gong, P. and Yu, Q. (2006) Quantity and Spatial Variability of Soil Carbon in the Conterminous United States. Soil Science Society of America Journal, 70, 590-600. http://dx.doi.org/10.2136/sssaj2005.0162

[8] Selhorst, A. and Lal, R. (2011) Carbon Budgeting in Golf Course Soils of Central Ohio. Urban Ecosystems, 14, 771-781. http://dx.doi.org/10.1007/s11252-011-0168-5

[9] Selhorst, A. and Lal, R. (2013) Net Carbon Sequestration Potential and Emissions in Home Lawn Turfgrass of the United States. Environmental Management, 51, 198-208. http://dx.doi.org/10.1007/s00267-012-9967-6

[10] Kong, L., Shi, Z. and Chu, L.M. (2014) Carbon Emission and Sequestration of Urban Turfgrass Systems in Hong Kong. Science of the Total Environment, 473-474, 132-138. http://dx.doi.org/10.1016/j.scitotenv.2013.12.012

[11] Haydu, J.J., Hodges, A.W. and Hall, C.R. (2012) Economic Impacts of the Turfgrass and Lawncare Industry in the United States. FE632, The Food and Resource Economics Department, Florida Cooperative Extension Service, Institute of Food and Agricultural Sciences, University of Florida.

[12] Milesi, C., Running, S.W., Elvidge, C.D., Dietz, J.B., Tuttle, B.T. and Nemani, R.R. (2005) Mapping and Modeling the Biogeochemical Cycling of Turf Grass in the United States. Environmental Management, 36, 426-438. http://dx.doi.org/10.1007/s00267-004-0316-2

[13] Robbins, P. and Birkenholtz, T. (2003) Turfgrass Revolution: Measuring the Expansion of the American Lawn. Land Use Policy, 20, 181-194. http://dx.doi.org/10.1016/S0264-8377(03)00006-1

[14] Schlesinger, W.M. (1999) Carbon Sequestration in Soils. Science, 284, 2095. http://dx.doi.org/10.1126/science.284.5423.2095

[15] Qian, Y., Follett, R.F. and Kimble, J.M. (2010) Soil Organic Carbon Input from Urban Turfgrasses. Soil Science Society of America Journal, 74, 366-371. http://dx.doi.org/10.2136/sssaj2009.0075

[16] Burt, R. (Ed.) (2004) Soil Survey Laboratory Methods Manual. Soil Survey Laboratory Investigations Report No. 42, USDA-NRCS, National Soil Survey Center, Lincoln.

[17] United States Environmental Protection Agency (USEPA) (2010) Terrestrial Carbon Sequestration: Field Guide for Sampling and Analysis at Sites Remediated with Soil Amend- 
ments. EPA-542-R-10-002.

http://www.cluin.org/download/issues/ecotools/terrestrial carbon seq field guide.pdf

[18] Townsend-Small, A. and Czimczik, C.I. (2010) Carbon Sequestration and Greenhouse Gas Emissions in Urban Turf. Geophysical Research Letter, 37, Article ID: L02707. http://dx.doi.org/10.1029/2009gl041675

[19] Lemma, B., Kleja, D.B., Olsson, M. and Nilsson, I. (2007) Factors Controlling Soil Organic Carbon Sequestration under Exotic Tree Plantations: A Case Study Using the $\mathrm{CO}_{2}$ FIX Model in Southwestern Ethiopia. Forest Ecology and Management, 252, 124-131. http://dx.doi.org/10.1016/j.foreco.2007.06.029

[20] Tate, K.R., Ross, D.J., O’Brien, B.J. and Kelliher, F.M. (1993) Carbon Storage and Turnover, and Respiratory Activity in the Litter and Soil of an Old-Growth Southern Beech (Nothofagus) Forest. Soil Biology and Biochemistry, 25, 1601-1612. http://dx.doi.org/10.1016/0038-0717(93)90016-5

[21] Jackson, R.B., Schenk, H.J., Jobbagy, E.G., Canadell, J., Colello, G.D., Dickinson, R.E., Field, C.B., Friedlingstein, P., Heimann, M., Hibbard, K., Kicklighter, D.W., Kleidon, A., Neilson, R.P., Parton, W.J., Sala, O.E. and Sykes, M.T. (2000) Belowground Consequences of Vegetation Change and Their Treatment in Models. Ecological Applications, 10, 470-483. http://dx.doi.org/10.1890/1051-0761(2000)010[0470:BCOVCA]2.0.CO;2

[22] Montagnini, F. and Nair, P.K.R. (2004) Carbon Sequestration: An Under-Exploited Environmental Benefit of Agroforestry Systems. Agroforestry Systems, 61, 281-295. http://dx.doi.org/10.1023/B:AGFO.0000029005.92691.79

[23] Reyes-Reyes, G., Baron-Ocampo, L., Cuali-Alvarez, I., Frias-Hernandez, J.T., Olalde-Portugal, V., Fregoso, L.V. and Dendooven, L. (2002) Carbon and Nitrogen Dynamics in Soil from the Central Highlands of Mexico as Affected by Mesquite (Prosopis spp.) and Huizache (Acacia tortuoso): A Laboratory Investigation. Applied Soil Ecology, 19, 27-34. http://dx.doi.org/10.1016/S0929-1393(01)00169-X

[24] Yelenik, S.G., Stock, W.D. and Richardson, D.M. (2004) Ecosystem Level Impacts of Invasive Acacia saligna in the South African Fynbos. Restoration Ecology, 12, 44-51. http://dx.doi.org/10.1111/j.1061-2971.2004.00289.x

[25] Haile, S.G., Nair, P.K.R. and Nair, V.D. (2008) Carbon Storage of Different Soil-Size Fractions in Florida Silvopastoral Systems. Journal of Environmental Quality, 27, 1789-1797. http://dx.doi.org/10.2134/jeq2007.0509

[26] Nickerson, C., Ebel, R., Borchers, A. and Carriazo. F. (2011) Major Uses of Land in the United States, 2007. EIB-89. US Department of Agriculture, Economic Research Service. Washington DC. http://www.ers.usda.gov/publications/eib-economic-information-bulletin/eib89.aspx

[27] Wohlfahrt, G., Fenstermaker, L.F. and Arnone, J.A. (2008) Large Annual net Ecosystem $\mathrm{CO}_{2}$ Uptake of a Mojave Desert Ecosystem. Global Change Biology, 14, 1475-1487. http://dx.doi.org/10.1111/j.1365-2486.2008.01593.x

[28] Hamido, S.A., Wood, C.W. and Guertal, E.A. (2016) Carbon Dioxide Flux from Bermudagrass Turf as Affected by Nitrogen Rate. Agronomy Journal, 108, 1000-1006. http://dx.doi.org/10.2134/agronj2015.0498

[29] Hamido, S.A., Guertal, E.A. and Wood, C.W. (2016) Nitrogen Fertilization of Bermudagrass Affects Carbon Dioxide Emissions. Golf Course Management, 5, 88-91. http://gcmdigital.gcsaa.org/i/669007-may-2016/9 
Submit or recommend next manuscript to SCIRP and we will provide best service for you:

Accepting pre-submission inquiries through Email, Facebook, LinkedIn, Twitter, etc. A wide selection of journals (inclusive of 9 subjects, more than 200 journals)

Providing 24-hour high-quality service

User-friendly online submission system

Fair and swift peer-review system

Efficient typesetting and proofreading procedure

Display of the result of downloads and visits, as well as the number of cited articles

Maximum dissemination of your research work

Submit your manuscript at: http://papersubmission.scirp.org/

Or contact gep@scirp.org 